\title{
The Physicochemical Properties and Composition of Biomass Ash and Evaluating Directions of its Applications
}

\author{
Jan Kalembkiewicz*, Dagmara Galas, Elżbieta Sitarz-Palczak \\ Department of Inorganic and Analytical Chemistry, Rzeszów University of Technology, Rzeszów, Poland
}

Received: 3 October 2017

Accepted: 28 November 2017

\begin{abstract}
We researched industrial wood ash in order to assess its posed threats and possible applications. The ash is type $\mathrm{S}$; due to the content of $\mathrm{SiO}_{2}, \mathrm{CaO}, \mathrm{Al}_{2} \mathrm{O}_{3}, \mathrm{~K}_{2} \mathrm{O}, \mathrm{Fe}_{2} \mathrm{O}_{3}, \mathrm{Na}_{2} \mathrm{O}, \mathrm{MgO}, \mathrm{SO}_{3}$, and $\mathrm{TiO}_{2}$ it is alkaline ( $\mathrm{pH}=12.9)$ with small bulk density $(<1.4 \mathrm{~g} / \mathrm{mL})$; and it is characterized by high fragmentation and irregularly shaped grains (research SEM/EDS). It has a high cationic-exchange capacity $(56 \mathrm{mmol} / 100 \mathrm{~g})$ and a negatively-charged surface $\left(\mathrm{pH}>\mathrm{pH}_{\mathrm{PZC}}\right)$, which suggests the possibility of sorption cations. Research of the structure of phases present in the ash (FT-IR method) and physical or chemical changes with their accompanied thermal effects in the temperature range 25-900 (TG/DTG method) indicate no degradation of aluminum-silicon skeletons. Metals occur inside and in the surface layer of the grain (FAAS, SEM/EDS analyses). Research of fractionation of $\mathrm{Cd}, \mathrm{Co}, \mathrm{Cr}$, $\mathrm{Cu}, \mathrm{Fe}, \mathrm{Mn}, \mathrm{Ni}, \mathrm{Pb}$, and $\mathrm{Zn}$ (classic Tessier's method) indicated high mobility among others (Co 28.44\%, $\mathrm{Cr} 20.49 \%$, and $\mathrm{Pb} 16.51 \%$ ), which poses a risk of environmental pollution. The obtained results indicate 2 directions of ash application: (i) limited environmental due to heavy metal and (ii) processing in geopolymer.
\end{abstract}

Keywords: biomass ash, environment, heavy metal fractionation, ash utilization, wood ash composition

\section{Introduction}

In recent years power plants have implemented systems for generating energy from renewable sources, using as fuel biomass co-firing with coal or independently [1-3], with a forecast of a significant increase in their share in energy production [4]. Effects on the properties and composition of the ash have the technological process and the starting material, which results in industrial biomass ash (BA) being significantly different than coal ash [4-

*e-mail: kalembic@prz.edu.pl
7]. Biomass ashes contain significant amounts of plant nutrients, mainly $\mathrm{Ca}, \mathrm{K}$, and microelements, which direct them to use in fertilization [8]. Additionally, biomass ash has a high neutralizing potential, which means it can be used as a substitute for lime fertilizer in reclamation work [9]. However, biomass ash can be a significant environmental challenge [10], which is mainly due to its chemical composition and properties that pose the threat of environmental pollution.

Ash from the combustion of woody biomass have higher content of $\mathrm{CaO}, \mathrm{MgO}, \mathrm{Na}_{2} \mathrm{O}, \mathrm{K}_{2} \mathrm{O}$, and $\mathrm{P}_{2} \mathrm{O}_{5}$, and lower content of $\mathrm{SiO}_{2}, \mathrm{Al}_{2} \mathrm{O}_{3}, \mathrm{Fe}_{2} \mathrm{O}_{3}$, and $\mathrm{SO}_{3}$ (in relation to coal ash) [11-13]. In biomass ash we identified many 
mineral species, including $\mathrm{Ca}-\mathrm{K}-\mathrm{Mn}$ silicates, $\mathrm{K}-\mathrm{Na}-\mathrm{Ca}$ chlorides, Ca-Al-Mn oxides, K-Ca-Mg-Na carbonates, sulphates, and phosphates - which do not occur in coal ash. Also, many Al-, Si-, Fe-, and Ti-bearing minerals typical for coal ash are not existed in biomass ash [11]. Despite the general belief in the beneficial impact of biomass ash on the environment, numerous research has indicated the presence of heavy metals in biomass ash, and their content depends primarily on the type of biomass burned [14]. Concentrations of metals in wood ash varies in wide ranges: $\mathrm{Cd} 1-41 \mathrm{mg} / \mathrm{kg}$ [15-30], Co 3-27 mg/kg [17, 19-21, 23, 27, 29], Cr 11-9914 mg/kg [15-17, 20-32], $\mathrm{Cu} 13-8793 \mathrm{mg} / \mathrm{kg}$ [15-34], Ni 3-510 mg/kg [15-30, 32], $\mathrm{Pb} 3-1900 \mathrm{mg} / \mathrm{kg}$ [15-30, 32, 34], Zn 0.01-1.21\% [15-34], and Mn 0.17-2.37\% [15, 18, 20-22, 24-25, 27, 29-30, 34]. In researching mobility of metals we used many methods, i.e., Tessier [35], BCR [36], and Prudent [37]. The high content of heavy metal in wood ash - especially their mobile forms under environmental conditions [38] - is a limiting factor for the direct environmental application of ash. It is also not recommended to use pellets based on biomass ash with the addition of bentonite as a binder material for fertilizer purposes, due to the high degree of uptake of $\mathrm{Cr}, \mathrm{Cd}, \mathrm{Cu}, \mathrm{Mn}$, and $\mathrm{Ni}$ by plants in acid soils [39].

Therefore we are seeking alternative directions for the use of biomass ash, which restrict the flow of heavy metal into the environment. The literature data indicate their application in construction materials [32], synthetic zeolites [40], sorbents [9], and geopolymers [41]. In order to assess the flow of heavy metal to the environment from industrial wood ash and the direction of its application, the research of physicochemical properties and chemical composition of ash, morphology, and mapping elements in micro-regions (grains), fractionation, and mobility of metals using SEM/EDS, FT-IR, TG-DTG, FAS, and sequential extraction methods were performed.

\section{Materials and Methods}

\section{Sample Collection and Preparation}

The object of the research was the ash from the heat and power station in Arłamów in Poland (49 $34^{\prime} 33^{\prime \prime} \mathrm{N}$ $22^{\circ} 40^{\prime} 05^{\prime \prime} \mathrm{E}$ ), being the product of combustion of wood chips and waste (from deciduous trees). The ash was sampled from installation (weight of sample $\approx 5 \mathrm{~kg}$ ), according to Polish standard PN-77/G-04528/0, transported to a laboratory and dried at room temperature for 14 days until getting to an air-dried state and being applied to granulometric analysis. To other research biomass ash has been triturated consecutively in ceramic and agate mortar $(\varphi \leq 100 \mu \mathrm{m})$. Such prepared biomass ash was stored in a hermetically closed container (PE). Polyethylene bottles were previously soaked in a $10 \%$ nitric acid bath overnight and washed thoroughly in double-distilled water.

\section{Reagents and Instrumentation}

All chemicals and reagents were of analytical grade or higher purity and were obtained from POCH and CHEMPUR, Poland. The solutions were prepared by dissolving appropriate compounds in double-distilled water from a water purification system (SolPure 7 POLL LAB, Poland). Standard solutions were prepared from standard solutions for flame atomic absorption (Sigma-Aldrich Chemie GmbH, Switzerland), and the concentrations of all metals in standard solutions were the same at $1.000 \mu \mathrm{g} / \mathrm{mL}$ in $1 \%$ of $\mathrm{HNO}_{3}$. Working standard solutions containing $\mathrm{Ca}, \mathrm{Cd}, \mathrm{Co}, \mathrm{Cr}, \mathrm{Cu}, \mathrm{Fe}, \mathrm{K}, \mathrm{Mg}, \mathrm{Mn}$, $\mathrm{Na}, \mathrm{Ni}, \mathrm{Pb}$, and $\mathrm{Zn}$ were prepared by serial dilution of the appropriate standard solution for flame atomic absorption. Determining the concentrations of metals in solutions from sequential extraction and mineralization were performed by a PERKIN-ELMER 3100 flame absorption spectrometer (Shelton Instruments, CT, USA).

\section{Physicochemical Characteristics of Biomass Ash Samples}

Physicochemical properties of biomass ash were determined according to standard procedures used for characterizing combustion by-products. Humidity of biomass ash was carried out with the use of a moisture balance method with the use of a moisture analyzer (MAX50/1, Radwag, Poland). During the analysis, the step profile was set up at the following temperatures: $40^{\circ} \mathrm{C}, 60^{\circ} \mathrm{C}$, and $98^{\circ} \mathrm{C}$. Loss on ignition was determined with the use of a muffle furnace (FCF 12SM, Czylok, Poland) at $900^{\circ} \mathrm{C}$. Roasting was performed for 2 hours until the constant mass was received. The bulk density was determined in an uncompressed and density state. Analyses were conducted for 2 diameters of grains: $0.5 \mathrm{~cm}$ and $0.25 \mathrm{~cm}$. The grain size distribution of biomass ash was determined by the sieving method. Sieve analysis was carried out with the use of five sieves of decreasing diameter of mesh: $0.5 \mathrm{~mm}, 0.25 \mathrm{~mm}, 0.12 \mathrm{~mm}, 0.2 \mathrm{~mm}$, and $0.088 \mathrm{~mm}$ (one on another, respectively). Marking $\mathrm{pH}$ of ash was carried out in distilled water $(\mathrm{pH}=7)$ and neutral salt solutions of $1 \mathrm{M} \mathrm{KCl}$ and $0.01 \mathrm{M} \mathrm{CaCl}_{2}$. Measuring $\mathrm{pH}$ was performed using a properly calibrated pHmeter (CP-501, Elmetron, Poland) equipped with a glass electrode (Eurosensor, Poland). Analyses were performed in triplicate and presented results are an arithmetic mean of those 3 trials.

\section{Infrared Absorption Spectroscopy (FT-IR)}

Powder preparations for the analysis were prepared by mixing the analyzed sample with spectrally pure $\mathrm{KBr}$. The product in the form of a pill was formed after pressing the prepared mixture in a vacuum at $10 \mathrm{MPa}$ pressure. The infrared spectra of absorption were recorded in the basic level between 4,000-400 $\mathrm{cm}^{-1}$ with a resolution of $2 \mathrm{~cm}^{-1}$ with Bruker (Germany) FT-IR ALPHA spectrometer. 


\section{Thermal Methods (TG, DTG)}

TG (thermogravimetric analysis) and DTG (differential thermogravimetric analysis) research was performed using a TGA/DSC1 analyzer (Mettler, Toledo, USA). The measurement was carried out in the temperature range $25-900^{\circ} \mathrm{C}$ with a constant heating rate of $10^{\circ} \mathrm{C} / \mathrm{min}$ in an air atmosphere.

\section{Chemical Composition of Biomass Ash}

The biomass ash samples $(10 \mathrm{~g})$ were mineralized with $\mathrm{HNO}_{3}$ (conc.) and $\mathrm{HClO}_{4}$ (conc.) mixtures in a volumetric ratio of 2:1 (33 mL:16.5 mL). The process was carried out in a teflon crucible on a hot plate (HP 88720-26 Barnstead/Thermolyne, USA) at $98^{\circ} \mathrm{C}$ under atmospheric pressure conditions until full evaporation of acid mixtures was achieved. Each sample was filled with distilled water after cooling down, filtering through a quantitative filter, being acidified with $2 \mathrm{M} \mathrm{HNO}_{3}$, and made up to the mark with water. Mineralization was carried out in triplicate. Content of metals $(\mathrm{Ca}, \mathrm{Cd}, \mathrm{Co}, \mathrm{Cr}$, $\mathrm{Cu}, \mathrm{Fe}, \mathrm{K}, \mathrm{Mg}, \mathrm{Mn}, \mathrm{Na}, \mathrm{Ni}, \mathrm{Pb}, \mathrm{Zn}$ ) in received effluents was determined with the use of flame atomic absorption spectrometry (FAAS). Content of nonmetals (C, H, N, S) was determined with the direct elemental analysis and the use of an elemental analyzer (Vario EL III Elementar, Germany).

\section{The Morphology of Biomass Ash}

The morphology of biomass ash grains was examined using a scanning electron microscope (S-3400N, Hitachi) equipped with an adapter for chemical analysis in micro-regions (EDS - energydispersive x-ray spectroscopy) and enabling observation of material surface with magnification ranging 5-100,000x. Preparations were prepared by placing the biomass ash sample on the coal belt with gold dusting. In order to determine the morphology of biomass ash grains,
16 microscopic images were made and we analyzed the chemical composition in micro-regions.

\section{The Sequential Extraction}

The sequential extraction was carried out according to Tessier procedure [35], including preliminary leaching with distilled water and dissolution in $\mathrm{HNO}_{3} / \mathrm{HClO}_{4}$ mixture after the fourth stage of extraction [42]. Content of $\mathrm{Cd}, \mathrm{Co}, \mathrm{Cr}, \mathrm{Cu}, \mathrm{Fe}, \mathrm{Mn}, \mathrm{Ni}, \mathrm{Pb}$, and $\mathrm{Zn}$ was determined in effluents after each stage of sequential extraction and converted to ash dry weight. We determined metals concentrations using flame atomic absorption spectrometry (FAAS). The analysis was conducted on 9 parallel samples. Steps to reproduce along with used reagents and process conditions are provided in Table 1.

\section{Point of Zero Charge of Biomass Ash}

The point of zero charge (PZC) was determined using the solid addition method [43]. Suspensions of $0.5 \mathrm{~g}$ of biomass ash were put into contact with $50 \mathrm{~mL}$ of $0.1 \mathrm{M}$ $\mathrm{NaNO}_{3}$ solutions with different $\mathrm{pH}$ values (3-14), adjusted with $\mathrm{HNO}_{3}$ and $\mathrm{NaOH}$. The suspensions were agitated for $8 \mathrm{~h}$ in a shaker at $350 \mathrm{rpm}$ until an equilibrium $\mathrm{pH}$ value was reached. After this time each resulting final $\mathrm{pH}$ was measured and the initial $\mathrm{pH}$ vs. the difference between the final and initial $\mathrm{pH}$ values was plotted, and the PZC was taken as the point where $\Delta \mathrm{pH}=0$.

\section{Cation-Exchange Capacity of Biomass Ash}

The cation-exchange capacity (CEC) for biomass ash was determined by sorption of methylene blue. $2 \cdot 10^{-3} \mathrm{~mol} / \mathrm{L}$ methylene blue solution was added to biomass ash samples and shaken for 20 minutes. Then samples were filtered and supplemented to a constant volume. In the solutions, using the JASCO V-670 spectrometer, the absorbance at $665 \mathrm{~nm}$ was measured, which corresponds to the maximum absorbance

Table 1. The conditions of sequential extraction of $\mathrm{Cd}, \mathrm{Co}, \mathrm{Cr}, \mathrm{Cu}, \mathrm{Fe}, \mathrm{Mn}, \mathrm{Ni}, \mathrm{Pb}$, and $\mathrm{Zn}$ from biomass ash by modified Tessier method.

\begin{tabular}{|c|c|c|c|c|c|}
\hline Stage & Fraction metal & Conditions of sequential extraction & Stage & $\begin{array}{c}\text { Fraction } \\
\text { metal }\end{array}$ & Conditions of sequential extraction \\
\hline 0 & Soluble in water & $\begin{array}{c}\mathrm{H}_{2} \mathrm{O}(\mathrm{pH}=7) \\
\mathrm{t}=1 \mathrm{~h}, \mathrm{~T}=20^{\circ} \mathrm{C} \\
\text { mixing }- \text { constantly }\end{array}$ & 3 & Oxide & $\begin{array}{c}0.04 \mathrm{M} \mathrm{NH}_{2} \mathrm{OH} \cdot \mathrm{HCl} \text { in } 25 \% \mathrm{CH}_{3} \mathrm{COOH} \\
\mathrm{t}=5 \mathrm{~h}, \mathrm{~T}=96^{\circ} \mathrm{C}, \\
\text { mixing - periodic }\end{array}$ \\
\hline \multirow[b]{2}{*}{1} & \multirow[b]{2}{*}{ Exchangeable } & \multirow{2}{*}{$\begin{array}{l}1 \mathrm{M} \mathrm{MgCl}_{2}(\mathrm{pH}=7) \\
\mathrm{t}=1 \mathrm{~h}, \mathrm{~T}=20^{\circ} \mathrm{C} \\
\text { mixing }- \text { constantly }\end{array}$} & \multirow[b]{2}{*}{4} & \multirow[b]{2}{*}{$\begin{array}{l}\text { Pseudo- } \\
\text { sulfide }\end{array}$} & $\begin{array}{l}30 \% \mathrm{H}_{2} \mathrm{O}_{2}(\mathrm{pH}=2) \\
\mathrm{t}=5 \mathrm{~h}, \mathrm{~T}=85^{\circ} \mathrm{C} \\
\text { mixing }- \text { periodic }\end{array}$ \\
\hline & & & & & $\begin{array}{l}3.2 \mathrm{M} \mathrm{CH}_{3} \mathrm{COONH}_{4} \\
\text { in } 20 \% \mathrm{HNO}_{3} \\
\mathrm{t}=1 \mathrm{~h}, \mathrm{~T}=20^{\circ} \mathrm{C} \\
\text { mixing - periodic }\end{array}$ \\
\hline 2 & $\begin{array}{c}\text { Soluble in acetate } \\
\text { buffer }\end{array}$ & $\begin{array}{c}\mathrm{CH}_{3} \mathrm{COOH} / \mathrm{CH}_{3} \mathrm{COONa} \\
(\mathrm{pH}=5) \\
\mathrm{t}=5 \mathrm{~h}, \mathrm{~T}=20^{\circ} \mathrm{C} \\
\text { mixing }- \text { constantly }\end{array}$ & 5 & Residual & $\begin{array}{c}\mathrm{HNO}_{3 \text { conc }} / \mathrm{HClO}_{4 \text { conc }} 2: 1(\mathrm{v} / \mathrm{v}) \\
\mathrm{t}=5 \mathrm{~h}, \mathrm{~T}=96^{\circ} \mathrm{C} \\
\text { mixing }- \text { periodic }\end{array}$ \\
\hline
\end{tabular}


for methylene blue. On this base the cation-exchange capacity value for the biomass ash was calculated.

\section{Results and Discussion}

\section{Physicochemical Properties}

The analyzed biomass ash has a dark gray color characteristic for products of woody biomass combustion. The biomass ash samples have hygroscopic properties that cause the grains to stick together, forming aggregates. Water percentage, determined at $98^{\circ} \mathrm{C}$ in the investigated biomass ash, amounts to $0.58 \%( \pm 0.05)$, so tested biomass ash can be classified as dry ash, which has strongly dusty properties (moisture content of ash $0-5 \%$ ). Loss on ignition, determined at $900^{\circ} \mathrm{C}$, amounts to $5.36 \%( \pm 0.01)$, which may indicate a high content of unburned coal and decompose many minerals in analyzed combustion waste. The investigated ash meets the requirements for categories $\mathrm{B}$ of ash $(2 \%<\mathrm{LOI}<7 \%$, according to Polish standard PN-EN 450-1:2012), which is very important in the application of the ash as an additive to concrete. Loss on ignition is increased together with water demand of ash, which lowers the durability of concrete [44]. The sieve analysis of biomass ash showed that the predominant fractions are particles of a smaller diameter than $0.088 \mathrm{~mm}(40.5 \%)$. It should be noted that the

a)

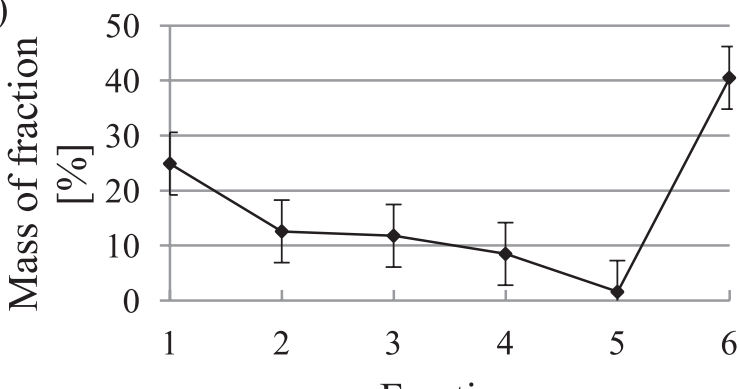

b)

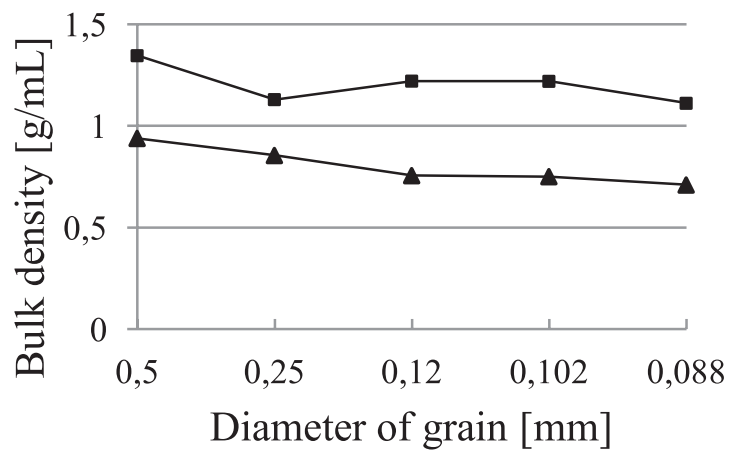

Fig. 1. The properties of biomass ash: A. Granulometric composition: fraction $1(\mathrm{x}>0.5)$, fraction $2(0.25<\mathrm{x}<0.5)$, fraction $3(0.12<\mathrm{x}<0.25)$, fraction $4(0.102<\mathrm{x}<0.12)$, fraction $5(0.088<\mathrm{x}<0.102)$, fraction $6(\mathrm{x}<0.088)$, $\mathrm{x}$-diameter of grain $[\mathrm{mm}]$, B. The bulk density in uncompressed ( $\boldsymbol{\Delta})$ and density ( $\boldsymbol{(})$ state depending on the grain size of ash. analyzed material is characterized by a large comminution (Fig. 1a). The size of biomass ash particles, their morphology, quantity, and the amount of space between them determines the value of ash bulk density. The bulk density of analyzed biomass ash in an uncompressed state (and density state) decreases from 0.94 to $0.71 \mathrm{~g} / \mathrm{mL}$ (1.35 to $1.11 \mathrm{~g} / \mathrm{mL}$ ) along with decreasing waste grain diameter (Fig. 1b). The literature data [45-46] indicated that bulk density of wood ash is changing across a wide range. The low bulk density in an uncompressed state with the absence cohesiveness of ash is the reason for their high susceptibility to dusting. The $\mathrm{pH}$ of combustion byproducts from woody biomass may vary in a wide range (from 9 to 13.5). If the molar ratio of $\mathrm{Ca}$ in relation to $\mathrm{S}$ is larger than 2.5 , the wastes have an alkaline character [47-49]. The analyzed biomass ash in all investigated solutions is an alkaline $\left(12.95-\mathrm{H}_{2} \mathrm{O}, 12.94-0.1 \mathrm{M} \mathrm{KCl}\right.$, 12.90-0.01 $\mathrm{M} \mathrm{CaCl}_{2}$ ), and the criterion of molar ratio of $\mathrm{Ca}$ to $\mathrm{S}$ is satisfied.

The FT-IR spectroscopy can be used to describe both the structure of phases present in the ash and to identify the characteristic elements of the individual components of ash. Fig. 2 presents the FT-IR spectrum of ash $f$ rom biomass combustion. The use of a spectrogram revealed the presence typical for biomass ash [5051] bands related to vibrations of aluminum-silicon structures, i.e., Si-O $\left(1110 \mathrm{~cm}^{-1}, 1044 \mathrm{~cm}^{-1}\right)$ asymmetric stretching vibration, $\mathrm{Si}-\mathrm{O}-\mathrm{Si}\left(796 \mathrm{~cm}^{-1}\right)$ symmetric bridge stretching vibration, Al-Si-O $\left(571 \mathrm{~cm}^{-1}\right)$ symmetric stretching vibration, and $\mathrm{O}-\mathrm{Si}-\mathrm{O}$ bending vibrations related to the presence of silica glass and quartz $\left(467 \mathrm{~cm}^{-1}\right)$. The presence of two bands in the range of OH-group vibrations was noted in the FT-IR spectrum. The acute band $\left(3643 \mathrm{~cm}^{-1}\right)$ with small FWHM probably was derived from the regularly distributed group $\mathrm{OH}$ in the structure. The wide and strong band $\left(3416 \mathrm{~cm}^{-1}\right)$ with large FWHM is related to a randomly placed hydroxyl group in the structure. The small peak at wave number around $\sim 1600 \mathrm{~cm}^{-1}$ indicates adsorbed or associated water molecules. A spectral band at around $1423 \mathrm{~cm}^{-1}$ is characteristic of the asymmetric stretching vibrations $\mathrm{C}=\mathrm{O}$, which suggests the presence of carbonate compounds in a biomass ash sample. Vibrations in the vicinity of the wave number $680 \mathrm{~cm}^{-1}$ and peaks at $513 \mathrm{~cm}^{-1}$ also indicate the presence of silica formation: kaolinite, quartz, and mullite.

Thermal methods enable identification of processes (dehydration, decomposition, oxidation, polymorphic transitions, sintering, melting, etc.) that are developing specific mineral phases. The TG curves represent the instantaneous weight percentage of the biomass ash in relation to the initial weight. DTG allows for the detection of thermal effects that are accompanied by physical or chemical changes. The TG/DTG curves of biomass ash sample include two main reaction regions. Combustion of volatiles and devolatilization take place, which are more reactive parts and later on combustion of more complex and thermally stable structures and char-forming reactions take place [52]. Analysis of the TG and DTG curves 


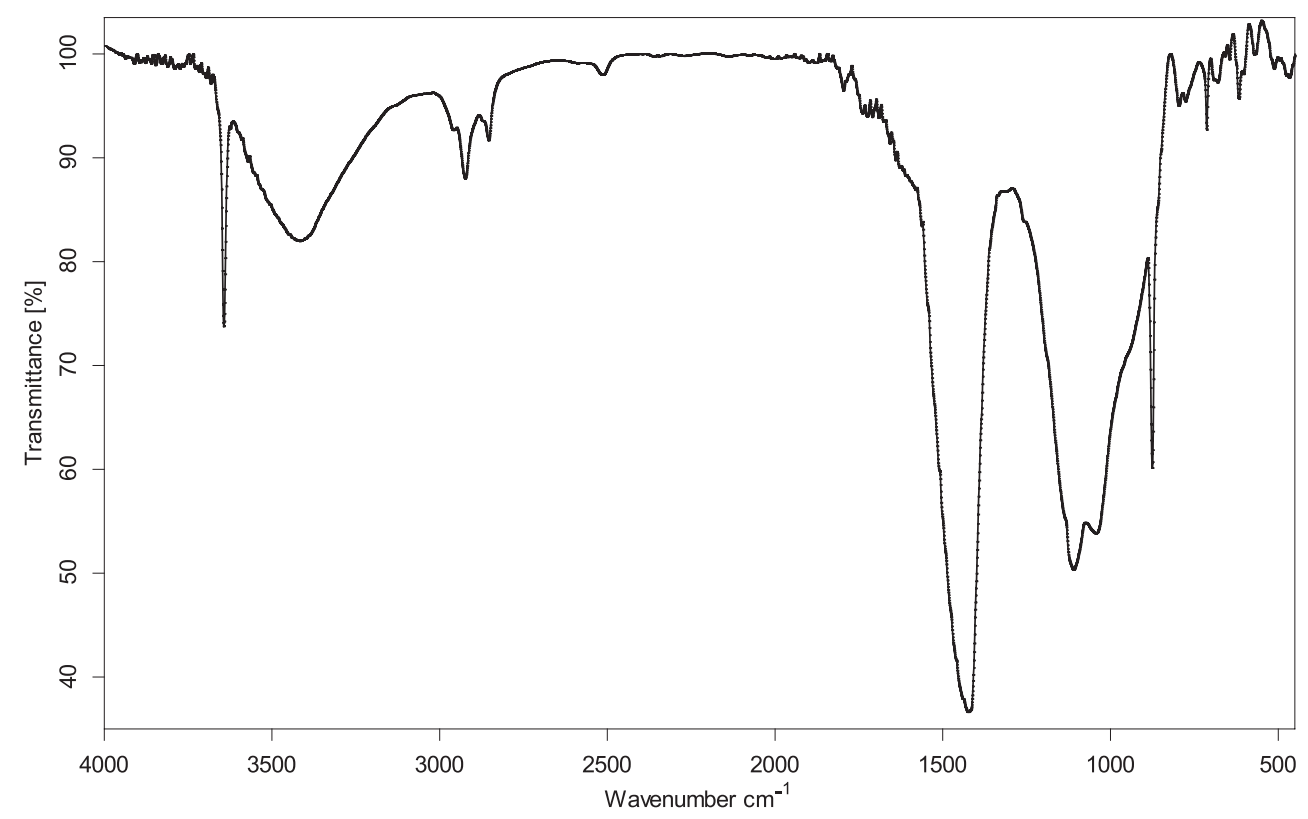

Fig. 2. FT-IR spectrum of biomass ash.

(Fig. 3) of investigated ash indicate 3 thermal effects: 1) the endothermic effect visible on the curve at $432^{\circ} \mathrm{C}$ and connected with the secretion of water from hydrated aluminates, silicates, and oxidation of residue organic matter, 2) the endothermic effect visible on the DTG curve at $636^{\circ} \mathrm{C}$ connected with $\mathrm{MgCO}_{3}$ decomposition, and 3) the endothermic effect visible on the DTG curve at $797^{\circ} \mathrm{C}$ connected with the $\mathrm{CaCO}_{3}$ decomposition. Thermal analysis of investigated biomass ash indicates the similar thermal effects as in the literature [53]. General loss by roasting the sample in the temperature up to $900^{\circ} \mathrm{C}$ amounts to approximately $3.05 \%$.

\section{Chemical Composition}

The content of analyzed elements in the biomass ash is diversified (Table 2). Major elements ( $>1 \%$ of dry weight of ash) include $\mathrm{C}, \mathrm{Ca}, \mathrm{Fe}$, and $\mathrm{Na}$, while minor elements $(1-0.1 \%)$ are $\mathrm{H}, \mathrm{K}, \mathrm{Mg}, \mathrm{Mn}, \mathrm{N}$, and $\mathrm{S}$. Trace components (less than $0.1 \%$ of dry weight) include mainly

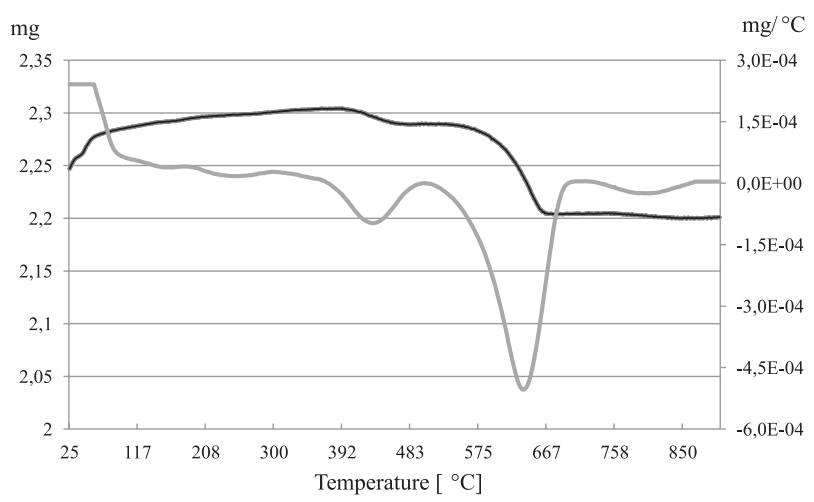

Fig. 3. TG/DTG curves of biomass ash (gray line - TG, black line - DTG).
$\mathrm{Cu}, \mathrm{Cd}, \mathrm{Co}, \mathrm{Cr}, \mathrm{Ni}, \mathrm{Pb}$, and $\mathrm{Zn}$. The waste from biomass is characterized by high content of substances an alkaline nature - in particular calcium, magnesium, sodium, and potassium oxide [11]. The content of metals in biomass ash is variable and depends on the type and origin of biomass, fertilizer, and pesticide doses used; harvesting time; collection technique; transport; storage; pollution; and combustion technology [14]. The concentrations of $\mathrm{Cd}, \mathrm{Co}, \mathrm{Cr}, \mathrm{Cu}, \mathrm{Mn}, \mathrm{Ni}, \mathrm{Pb}$, and $\mathrm{Zn}$ in investigated ash are in the typical range for wood ash (included in the introduction).

The total content of carbon in ash depends on the biomass type. Lower values of unburnt carbon were noted in ash from the combustion of deciduous wood chips than from coniferous trees [11, 54-55]. The analyzed biomass ash contains $3.5 \%$ of unburnt carbon, which indicates a high content of biomass char.

\section{The Morphology of Ash and Mapping Elements in the Micro-Regions: Research SEM/EDS}

Biomass ash grains are characterized by a complex morphology [56-57]. Noticeable is the dominant number of irregular particles. The size of individual grains ranges from less than $10 \mu \mathrm{m}$ to more than $1 \mathrm{~mm}$ (Fig. $4 \mathrm{a}$ ). The finest grains occur in the form of aggregates, which are building larger particles. Grains have both angular and rounded edges. The interiors of larger particles are filled with smaller ash particles (Fig. 4b). Also, in ash are spherical pyrospheres (on their surface are finer particles; Fig. 4c) and unburnt fragments of sharp-edged wood chips (Fig. 4d).

The EDS microanalysis enables identification and the distribution of elements in the specific area selected with the use of a scanning microscope [58]. The EDS analysis indicates the presence of aluminum, silicon, 
Table 2. The total content of the studied elements in the biomass ash determined by the FAAS method after mineralization of the biomass ash in the mixture of concentrated $\mathrm{HNO}_{3}$ and $\mathrm{HClO}_{4}$ (metals) and by elemental analysis (nonmetals).

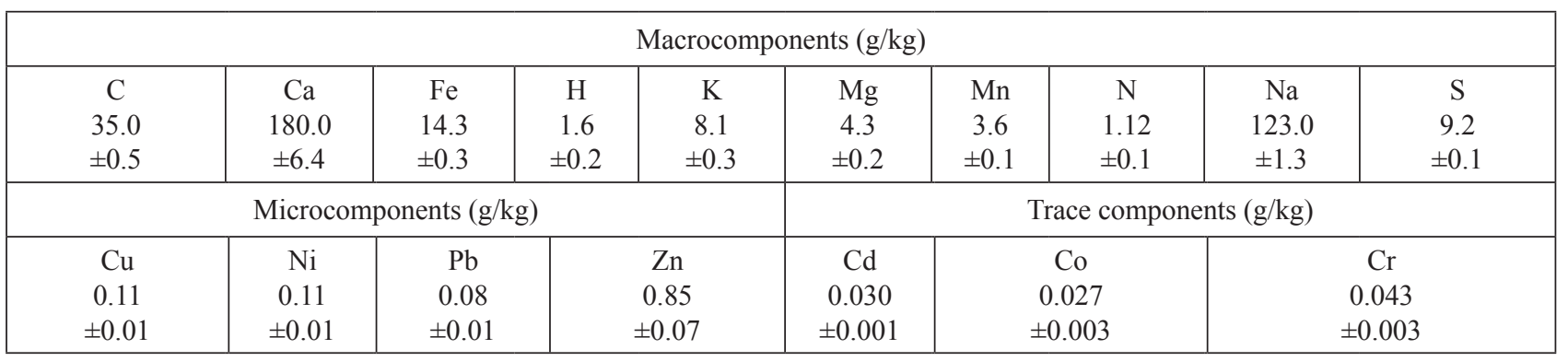

Data are presented - average value \pm standard deviation, $(n=9, p=95 \%)$

a)

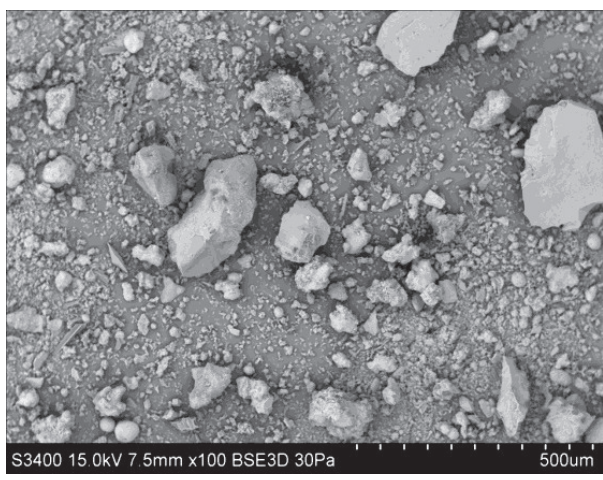

c)
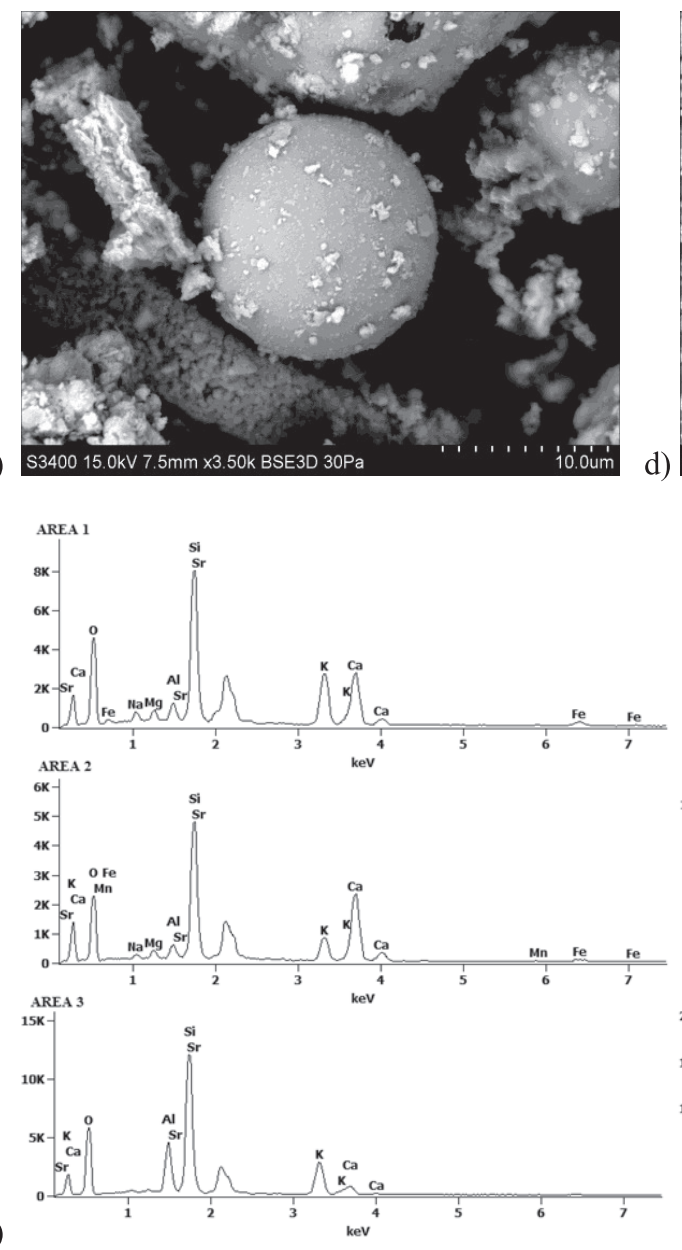
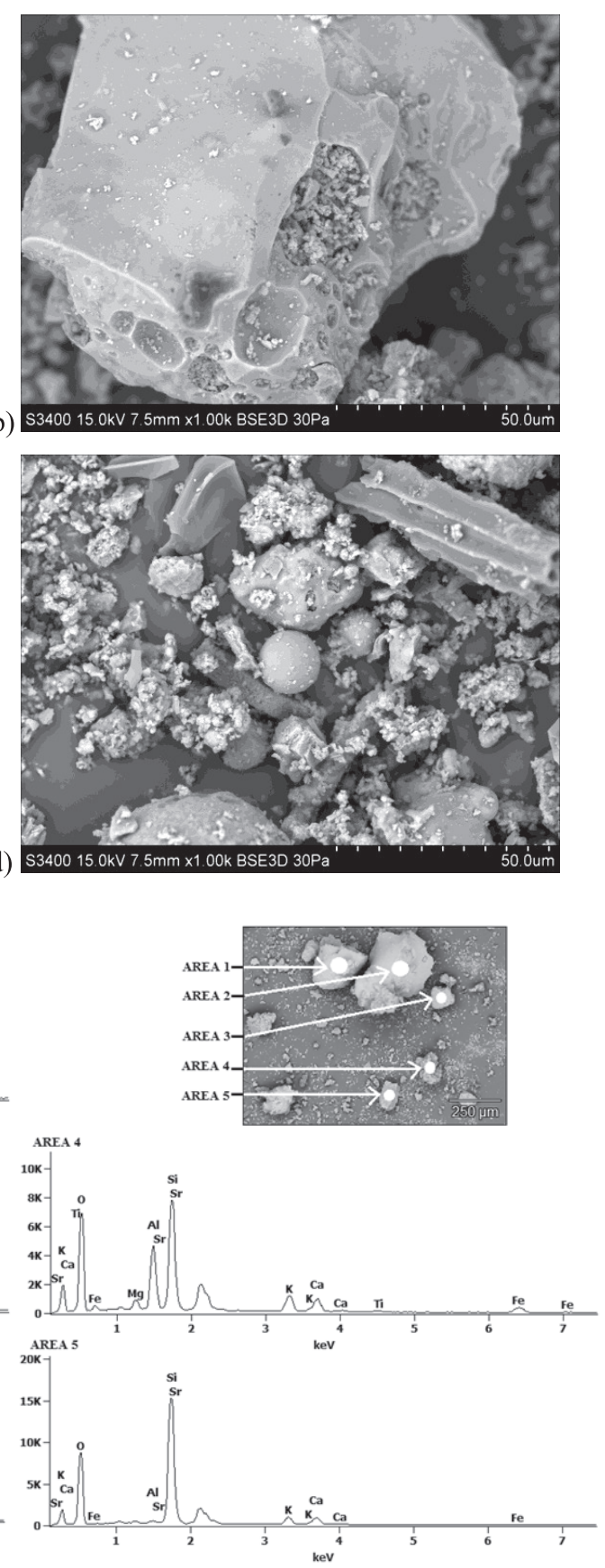

Fig. 4. a-d) The SEM images of biomass ash, e) The EDS spectra for biomass ash (1, 2, 3, 4, 5 - areas of study), (peak in area 2-3 keV derived from the $\mathrm{Au}$, which are dusted samples for EDS analysis). 
Table 3. The result of microanalysis EDS of biomass ash (*symbol element - symbol electron shell).

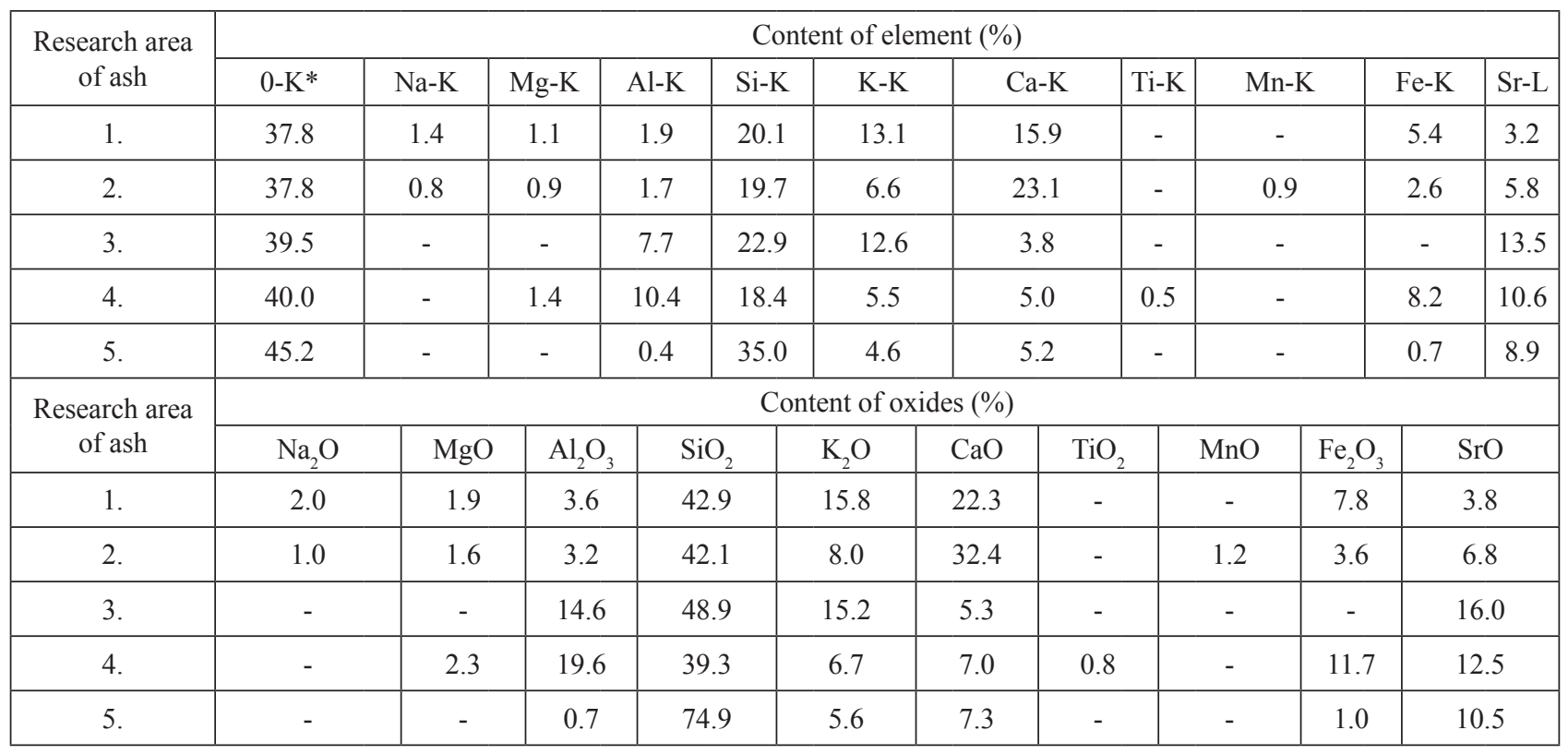

potassium, calcium, and strontium in all analyzed areas (Fig. 4e). In areas 1 and 2 (grains exceeding $250 \mu \mathrm{m}$ ) the presence of sodium, in areas 1, 2, and 3 the presence of magnesium, and in 1, 2, 4, and 5 the presence of iron. Furthermore, in a few individual areas the presence of manganese ( $0.9 \%$ wt.) and titanium $(0.5 \%$ wt.) were noted. Samples of biomass ash are highly volatile. Dispersion of chemical composition of grains is significant. Singlegrains of biomass ash may be built from a small number of compounds or can represent only one component.
Detailed data regarding EDS microanalysis are presented in Table 3.

The composition of the mineral phase of biomass ash was determined on the basis of EDS analysis (Table 3). Ash has typical chemical composition for ash from combustion woody biomass [14]. Due to the share of the main components of biomass ash (according to Polish standard BN-79/6722-09), it can be classified as siliceous ash (k) with $\mathrm{SiO}_{2}$ content exceeding $40 \%$ and $\mathrm{Al}_{2} \mathrm{O}_{3}$ content less than $30 \%$, and due to the content of $\mathrm{SiO}_{2}$,

Table. 4. The concentration of investigated metals $(\mathrm{mg} / \mathrm{kg})$ in individual chemical fraction of ash (detection limit, d.l. for $\mathrm{Cd}-0.028 \mathrm{mg} / \mathrm{L}, \mathrm{Co}-0.22 \mathrm{mg} / \mathrm{L}, \mathrm{Cr}-0.10 \mathrm{mg} / \mathrm{L}, \mathrm{Cu}-0.077 \mathrm{mg} / \mathrm{L}, \mathrm{Fe}-0.34 \mathrm{mg} / \mathrm{L}, \mathrm{Mn}-0.052 \mathrm{mg} / \mathrm{L}, \mathrm{Ni}-0.40 \mathrm{mg} / \mathrm{L}$, $\mathrm{Pb}-0.19 \mathrm{mg} / \mathrm{L}, \mathrm{Zn}-0.018 \mathrm{mg} / \mathrm{L})$.

\begin{tabular}{|c|c|c|c|c|c|c|c|c|c|c|c|}
\hline Metal & $\mathrm{Cd}$ & $\mathrm{Co}$ & $\mathrm{Cr}$ & $\mathrm{Cu}$ & $\mathrm{Fe}$ & $\mathrm{Mn}$ & $\mathrm{Ni}$ & $\mathrm{Pb}$ & $\mathrm{Zn}$ \\
\hline \multicolumn{7}{|c|}{ Content $(\mathrm{mg} / \mathrm{kg})$} \\
\hline $\begin{array}{c}\text { Soluble in water } \\
\text { fraction }\end{array}$ & $<\mathrm{d} .1$. & $\begin{array}{c}0.50 \\
\pm 0.01\end{array}$ & $\begin{array}{c}2.66 \\
\pm 0.29\end{array}$ & $<\mathrm{d} .1$. & $<\mathrm{d} .1$. & $\begin{array}{c}0.50 \\
\pm 0.01\end{array}$ & $<\mathrm{d} .1$. & $\begin{array}{c}1.50 \\
\pm 0.12\end{array}$ & $<\mathrm{d} .1$. \\
\hline $\begin{array}{c}\text { Exchangeable } \\
\text { fraction }\end{array}$ & 0.52 & 3.96 & 3.61 & 0.86 & 14.62 & 1.55 & 5.68 & 5.68 & $<\mathrm{d} .1$. \\
\hline $\begin{array}{c}\text { Soluble in acetale } \\
\text { buffer }\end{array}$ & 0.52 & 3.13 & 2.60 & 0.52 & 3.30 & 0.52 & 4.17 & 5.21 & $<\mathrm{d} .1$. \\
\hline Oxide fraction & 21.66 & 8.66 & 8.80 & 44.24 & 783.0 & 2529.9 & 30.7 & 19.94 & 517.3 \\
& \pm 1.25 & \pm 0.50 & \pm 0.50 & \pm 2.20 & \pm 6.2 & \pm 20.5 & \pm 0.3 & \pm 1.70 & \pm 12.5 \\
\hline $\begin{array}{c}\text { Pseudosulfide } \\
\text { fraction }\end{array}$ & 4.26 & 13.08 & 16.44 & 42.27 & 7614.2 & 961.9 & 61.5 & 51.44 & 248.9 \\
\pm 0.20 & \pm 0.55 & \pm 0.85 & \pm 1.90 & \pm 14.5 & \pm 15.0 & \pm 3.1 & \pm 3.00 & \pm 10.0 \\
\hline Residual & $<\mathrm{d} .1$. & $<\mathrm{d} .1$. & 17.72 & 16.61 & 5873.9 & 289.6 & 22.4 & $<\mathrm{d} .1$. & 102.0 \\
& & \pm 1.05 & \pm 0.95 & \pm 6.5 & \pm 3.9 & \pm 0.2 & \pm 2.5 \\
\hline$\sum_{\text {fractionF(0)-F(5) }}$ & 26.96 & 29.33 & 51.83 & 104.51 & $14.29 \mathrm{~g} / \mathrm{kg}$ & $3.78 \mathrm{~g} / \mathrm{kg}$ & 124.45 & 83.77 & 868.2 \\
\hline Recovery & $89.9 \%$ & $108.6 \%$ & $120.5 \%$ & $95 \%$ & $99.9 \%$ & $105.1 \%$ & $113.1 \%$ & $104.7 \%$ & $102.1 \%$ \\
\hline
\end{tabular}

Data are presented - average value \pm standard deviation, $(n=9, p=95 \%)$

Recovery was counted from the equation: [sum of fraction $\mathrm{F}(0)-\mathrm{F}(5) /$ total content] $\cdot 100 \%$ 
$\mathrm{CaO}, \mathrm{Al}_{2} \mathrm{O}_{3}, \mathrm{~K}_{2} \mathrm{O}, \mathrm{Fe}_{2} \mathrm{O}_{3}, \mathrm{Na}_{2} \mathrm{O}, \mathrm{MgO}, \mathrm{SO}_{3}$, and $\mathrm{TiO}_{2}$ can be classified as biomass ash type $\mathrm{S}$ [7]. On the basis of the molar ratio Si:Al, which depending on the study area is an average of 23 , which is in the range (10-100) for the high silicon materials [59], which are highly ion-exchangeable and hydrophobic. An important feature of ash is its pozzolanic properties, which determine the ability of the active ingredients of ash to react with lime and water to form a compound with the character of a permanent hydraulic binder. The average content of calcium oxide in the investigated ash is about $14 \%$, which allows the classified biomass ash to be active.

\section{Fractionation of Metals}

The sequential extraction enabled the isolation of 6 fractions of metals from the biomass ash: soluble in water, exchangeable, soluble in acetate buffer, oxide, pseudosulfide, and residual. Detailed data regarding the marked content of metals in the individual fractions is provided in Table 4. The content of metals (i.e., Cd, Co, $\mathrm{Cr}, \mathrm{Cu}, \mathrm{Fe}, \mathrm{Mn}, \mathrm{Ni}, \mathrm{Pb}$, and $\mathrm{Zn}$ ) in analyzed fractions is diverse. The fraction that is soluble in water contains the most bioavailable and mobile metals. In the analyzed ash the contents of $\mathrm{Cd}, \mathrm{Cu}, \mathrm{Fe}, \mathrm{Ni}$, and $\mathrm{Zn}$ in the water-soluble fraction was not detected. However, the dominant content of chromium in the form of this fraction $(2.66 \mathrm{mg} / \mathrm{kg})$ was noted. On the other hand, the exchangeable fraction includes mainly metals that are present in free form or in the form of complex ions. In this fraction iron $(14.62 \mathrm{mg} / \mathrm{kg})$, nickel $(5.68 \mathrm{mg} / \mathrm{kg})$ and lead $(5.68 \mathrm{mg} / \mathrm{kg}$ ) are dominant, while $\mathrm{Zn}$ is absent. The buffer fraction soluble in acetate includes mainly components soluble in the slightly acidic environment $(\mathrm{pH}=5)$. The contents of $\mathrm{Pb}(5.21 \mathrm{mg} / \mathrm{kg})$ and $\mathrm{Ni}(4.17 \mathrm{mg} / \mathrm{kg})$ are high in this fraction. Contents of $\mathrm{Cd}, \mathrm{Cu}$, and $\mathrm{Mn}$ are similar in this fraction and amount to $0.52 \mathrm{mg} / \mathrm{kg}$. The oxide fraction is composed of metals adsorbed on the surface of manganese and iron oxides. This fraction is characterized by a high content of manganese $(2529,9 \mathrm{mg} / \mathrm{kg})$ at low content of $\mathrm{Cr}(8.8 \mathrm{mg} / \mathrm{kg})$ and $\mathrm{Co}(8.66 \mathrm{mg} / \mathrm{kg})$. Iron $(7614.2 \mathrm{mg} / \mathrm{kg})$ and manganese $(961.9 \mathrm{mg} / \mathrm{kg})$ are the main metals in the pseudosulfide fraction. Contents of $\mathrm{Cd}, \mathrm{Co}$, and $\mathrm{Pb}$ in the residual fraction were not noted; however, the dominant content of iron $(5873.9 \mathrm{~g} / \mathrm{kg})$ was detected. The content of particularly dangerous metals occurring in ash from biomass, including $\mathrm{Pb}$ and $\mathrm{Cd}$ in all fractions (with the exception of $\mathrm{Pb}$ and $\mathrm{Cd}$ in residual and $\mathrm{Cd}$ in soluble in water) should be emphasized.

\section{Mobility of Metals}

Fractions of metals - soluble in water, exchangeable $(\mathrm{pH}=7)$, and soluble in acetate buffer $(\mathrm{pH}=5)$ - contain forms of metals which after leaching can easily penetrate into groundwater. Other fractions of metals remaining in
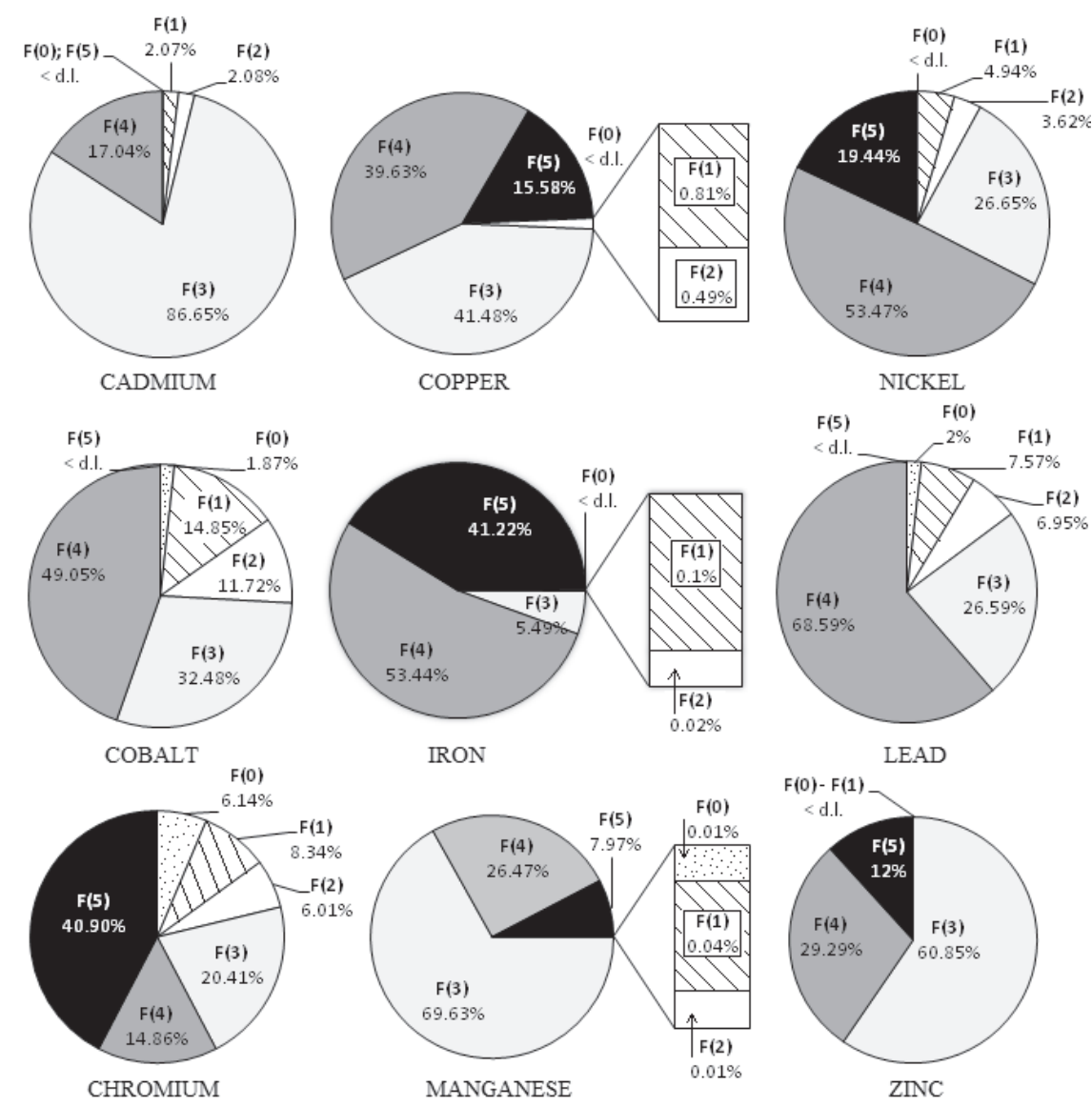

Fig. 5. The mobility of $\mathrm{Cd}, \mathrm{Cu}, \mathrm{Ni}, \mathrm{Co}, \mathrm{Fe}, \mathrm{Pb}, \mathrm{Cr}, \mathrm{Mn}$, and $\mathrm{Zn}$ in the biomass ash (F0, F1, F2 = environmentally mobile fractions). 
the ash can get into the environment only under specific conditions, i.e., with more aggressive extractants (oxide and pseudosulfide fraction), or with microorganisms (pseudosulfide and residual fraction) [60]. Mobile fractions of metals in environmental conditions (soluble in water, solution of magnesium chloride and acetate buffer) are as follows: $1.04 \mathrm{mg} / \mathrm{kg}(\mathrm{Cd}), 1.38 \mathrm{mg} / \mathrm{kg}(\mathrm{Cu})$, $2.57 \mathrm{mg} / \mathrm{kg}(\mathrm{Mn}), 7.59 \mathrm{mg} / \mathrm{kg}$ (Co), $8.87 \mathrm{mg} / \mathrm{kg}$ (Cr), $9.85 \mathrm{mg} / \mathrm{kg}(\mathrm{Ni}), 12.39 \mathrm{mg} / \mathrm{kg}(\mathrm{Pb})$, and $17.92 \mathrm{mg} / \mathrm{kg}(\mathrm{Fe})$. The presence of zinc in the analyzed biomass ash in the form of a mobile fraction was not detected.

The coefficient of metals mobility, which is an indicator of "environmentally active" forms of metal in relation to its total content in the biomass ash, was determined in accordance with the formula: $\alpha(\%)=\left(\sum_{\mathrm{i}=0}^{\mathrm{i}=2}[\mathrm{M}]_{\mathrm{i}} /[\mathrm{M}]_{\text {total }}\right) \times 100 \%$, where $[\mathrm{M}]_{\mathrm{i}}$ is metal concentration in a given fraction, $i$ is the number of the fraction, and $[\mathrm{M}]_{\text {total }}$ is total concentration of metal in biomass ash. The highest mobility, in relation to the total content, shows cobalt $28.44 \%$, chromium $20.49 \%$, and lead $16.51 \%$, and then mobility decreases in series: $\mathrm{Ni}>\mathrm{Cd}>\mathrm{Cu}>\mathrm{Mn}>\mathrm{Zn}$. The risk of inorganic contamination, especially by heavy metal resulting from the short-term and long-term storage of biomass ash, is the consequence of the highest mobility. The content of mobile fractions of metals in the biomass ash is presented in Fig. 5.

\section{Point of Zero Charge and Cation-Exchange Capacity of Biomass Ash}

Point of zero charge is a point where the net charge of variable charge components is zero due to the equal $\mathrm{H}^{+}$and $\mathrm{OH}^{-}$adsorption on them. If the $\mathrm{pH}$ of a sorbent is above its PZC, the surface will have a net negative charge and predominantly exhibit an ability to exchange cations, while the sorbent will mainly retain anions if its $\mathrm{pH}$ is below its PZC [61]. The point of zero charge determined by solid addition method for the investigated biomass ash is 11.5, which means that the surface of ash has a negative charge, alkaline nature, and the ability to exchange cations. Cation-exchange capacity determined the ability to adsorb cations from aqueous solution on an exchange basis. Cations that occur on the surface and in the interpackage spaces are desorbed and the cations from solution are adsorbed. CEC for investigated biomass ash is $56 \mathrm{mmol} / 100 \mathrm{~g}$ and is higher than for coal ash and clay minerals, e.g., kaolinite, chlorine, geothite, and gibbsie [62-63].

\section{Potential Application of Biomass Ash to Synthesis of Geopolymers}

The direct application of the biomass ash for agricultural purposes is limited due to the high mobility of metals, i.e. $\mathrm{Pb}, \mathrm{Cr}, \mathrm{Co}$. An alternative method of management of industrial ash is their use for the production of geopolymers. Geopolymers are a new class of inorganic, amorphous aluminosilicate polymers with specific composition and properties. Geopolymers are usually hard and mechanically resisting solids, reminiscent of natural stone or concrete. Geopolymers are obtained by a geopolymerization reaction that involves polycondensation of silicate anions. As a result, an inorganic polymer is obtained, the general formula of which is:

$\left.\mathrm{M}_{\mathrm{n}}\left[-\mathrm{SiO}_{2}\right)_{\mathrm{z}}-\mathrm{AlO}_{2}\right]_{\mathrm{n}} \cdot \mathrm{wH}_{2} \mathrm{O}$, where $\mathrm{M}$ is cation sodium, potassium, or calcium; $n$ is degree of polycondensation; and $\mathrm{z}$ is $1,2,3$. The properties of geopolymers depend on the nature of the base material used for their synthesis, the type and amount of activator, and the conditions of the polycondensation process [64-65]. Production of geopolymers based on biomass ash is a way of managing these wastes and allows for limiting the impact of these wastes on the environment.

\section{Conclusions}

1) The ash from woody biomass has different structure and grain construction relative to coal ash and is alkaline, with the predominant number of irregularly shaped grains and the characteristic uneven distribution of metal on the grain surface, which affects the alkalinity of the environment and the release of metals.

2) Independent of alkali ( $\mathrm{Na}, \mathrm{K})$ and alkaline earth $(\mathrm{Ca}, \mathrm{Mg})$ metals typical for biomass, investigated ash contains metals $(\mathrm{Cd}, \mathrm{Co}, \mathrm{Cr}, \mathrm{Cu}, \mathrm{Fe}, \mathrm{Mn}, \mathrm{Ni}, \mathrm{Pb}$, $\mathrm{Zn})$ that limit the direct environmental application of ash, and have high ion-exchangeability and hydrophobicity (Si:Al 23) properties that can affect the ion equilibrium in the environment.

3) Very important is the part of sulfur in the ash amounting to $9.2 \mathrm{~g} / \mathrm{kg}$ on the background of carbon content $(35 \mathrm{~g} / \mathrm{kg})$, which could have an impact on the further development of the ash and its impact on the environment.

4) The significant differences in content of metals in fractions in ash were noted. The predominant fractions are: oxide $(>40 \% \mathrm{Mn}, \mathrm{Zn}, \mathrm{Cu}, \mathrm{Cd})$, pseudosulfide $(>49 \% \mathrm{Fe}, \mathrm{Ni}, \mathrm{Co}, \mathrm{Pb})$, and residual $(40 \% \mathrm{Cr})$. Fractions metal able to migrate under the environmental conditions (water soluble $\mathrm{pH}$ 5-7, exchangeable) are the highest for Co $28.4 \%$, Cr $20.5 \%$, and $\mathrm{Pb} 16.5 \%$.

5) The ash has pozzolanic properties $(\mathrm{CaO} \sim 14 \%)$ and exhibits durability of aluminum-silicon structures in a wide temperature range (up to $900^{\circ} \mathrm{C}$ ), which can be attributed to non-agricultural applications of ash.

6) Although biomass ash has the ability to adsorb cations and high cation-exchange capacity, the high mobility $(>15 \%)$ of some metals $(\mathrm{Pb}, \mathrm{Cr}, \mathrm{Co})$ may limit direct agricultural application of the ash. One possible use of biomass ash is their application to the synthesis of geopolymers. 


\section{Acknowledgements}

The authors would like to thank Dr. Eng. M. Wierzbińska from the Department of Materials Science, Rzeszów University of Technology for conducting SEM/ EDS research.

\section{References}

1. NUNES L.J.R., MATIAS J.C.O., CATALÃO J.P.S. Biomass combustion systems: A review on the physical and chemical properties of the ashes. Renew. Sust. Energ. Rev. 53, 235, 2016.

2. SAHU S.G., CHAKRABORTY N., SARKAR P. Coalbiomass co-combustion: An overview. Renew. Sust. Energ. Rev. 39, 575, 2014.

3. PIWOWAR A., DZIKUĆ M. Outline of the economic and technical problems associated with the co-combustion of biomass in Poland. Renew. Sust. Energ. Rev. 54, 415, 2016.

4. GARCÍA R., PIZARRO C., LAVÍN A. G., BUENO J.L. Biomass sources for thermal conversion. Technoeconomical overview. Fuel 195, 182, 2017.

5. VASSILEV S.V., BAXTER D., ANDERSEN L.K., VASSILEVA C.G. An overview of the chemical composition of biomass. Fuel 89, 913, 2010.

6. KALEMBKIEWICZ J., CHMIELARZ U. Ashes from co-combustion of coal and biomass: new industrial waste. Resour. Conserv. Rec. 69, 109, 2012.

7. VASSILEV S.V., BAXTER D., VASSILEVA C.G. An overview of the behaviour of biomass during combustion: Part II. Ash fusion and ash formation mechanisms of biomass types. Fuel 117, 152, 2014.

8. SCHIEMENZ K., EICHLER-LÖBERMANN B. Biomass ashes and their phosphorus fertilizing effect on different crops. Nutr. Cycl. Agroecosys. 87, 471, 2010.

9. VASSILEV S.V., BAXTER D., ANDERSEN L.K., VASSILEVA C.G. An overview of the composition and application of biomass ash: Part 2. Potential utilisation, technological and ecological advantages and challenges. Fuel 105, 19, 2013.

10. AHMARUZZAMAN M. A review on the utilization of fly ash. Prog. Energ. Combust. Science 36, 327, 2010.

11. VASSILEV S.V., BAXTER D., ANDERSEN L.K., VASSILEVA C.G. An overview of the composition and application of biomass ash. Part 1. Phase-mineral and chemical composition and classification. Fuel 105, 44, 2013.

12. VASSILEV S.V., VASSILEVA C.G., BAXTER D. Trace element concentrations and associations in some biomass ashes. Fuel 129, 292, 2014.

13. LANZERSTORFER C. Chemical composition and physical properties of filter fly ashes from eight grate-fired biomass combustion plants. J. Environ. Sci. 30, 191, 2015.

14. VASSILEV S.V., VASSILEVA C.G., VASSILEV V.S. Advantages and disadvantages of composition and properties of biomass in comparison with coal: An overview. Fuel 158, 330, 2015.

15. QIN J., HOVMAND M.F., EKELUND F., RØNN R., CHRISTENSEN S., ARJEN DEGROOT G., MORTENSEN L.H., SKOV S., KROGH P.H. Wood ash application increases $\mathrm{pH}$ but does not harm the soil mesofauna. Environ. Pollut. 224, 581, 2017.

16. BUDHATHOKI R., VÄISÄNEN A. Particle size based recovery of phosphorus from combined peat and wood fly ash for forest fertilization. Fuel Process. Technol. 146, 85, 2016.

17. FERNÁNDEZ-DELGADO JUÁREZ M., PRÄHAUSER B., WALTER A., INSAM H., FRANKE-WHITTLE I.H. Co-composting of biowaste and wood ash, influence on a microbially driven-process. Waste Manage. 46, 155, 2015.

18. KIRKELUND G.M., DAMOE A.J., OTTOSEN L.M. Electrodialytic removal of $\mathrm{Cd}$ from biomass combustion fly ash suspensions. J. Hazard. Mater. 250-251, 212, 2013.

19. NABEELA F., MURAD W., KHAN I., MIAN I.A., REHMAN H., ADNAN M., AZIZULLAH A. Effect of wood ash application on the morphological, physiological and biochemical parameters of Brassica napus L. Plant Physiol. Bioch. 95, 15, 2015.

20. BRAIS S., BÉLANGER N., GUILLEMETTE T. Wood ash and $\mathrm{N}$ fertilization in the Canadian boreal forest: Soil properties and response of jack pine and black spruce. Forest Ecol. Manag. 348, 1, 2015.

21. FERNÁNDEZ-DELGADO JUÁREZ M., GÓMEZBRANDÓN M., INSAM H. Merging two waste streams, wood ash and biowaste, results in improved composting process and end products. Sci. Total Environ. 511, 91, 2015.

22. INGERSLEV M., HANSEN M., BOPEDERSEN L., SKOV S. Effects of wood chip ash fertilization on soil chemistry in a Norway spruce plantation on a nutrient-poor soil. Forest Ecol. Manag. 334, 10, 2014.

23. SAQIB N., BÄCKSTRÖM M. Trace element partitioning in ashes from boilers firing pure wood or mixtures of solid waste with respect to fuel composition, chlorine content and temperature. Waste Manage. 34, 2505, 2014.

24. OMIL B., PIÑEIRO V., MERINO A. Soil and tree responses to the application of wood ash containing charcoal in two soils with contrasting properties. Forest Ecol. Manag. 295, 199, 2013.

25. EBERHARDT T.L., PAN H. Analysis of the fly ash from the processing of wood chips in a pilot-scale downdraft gasifier: Comparison of inorganic constituents determined by PIXE and ICP-AES. Biomass Bioenerg. 51, 163, 2013

26. SAKTHIVEL S.R., TILLEY E., UDERT K.M. Wood ash as a magnesium source for phosphorus recovery from sourceseparated urine. Sci. Total Environ. 419, 68, 2012.

27. PARK N.D., RUTHERFORD P.M., THRING R.W., HELLE S.S. Wood pellet fly ash and bottom ash as an effective liming agent and nutrient source for rye grass (Lolium perenne L.) and oats (Avena sativa). Chemosphere 86, 427, 2012.

28. CHEAH C. B., RAMLI M. The implementation of wood waste ash as a partial cement replacement material in the production of structural grade concrete and mortar: An overview. Resour. Conserv. Recy. 55, 669, 2011.

29. STEENARI B.M., KARLFELDT FEDJE K. Addition of kaolin as potassium sorbent in the combustion of wood fuel - Effects on fly ash properties. Fuel 89, 2026, 2010.

30. ROSENBERG O., PERSSON T., HÖGBOM L., JACOBSON S. Effects of wood-ash application on potential carbon and nitrogen mineralisation at two forest sites with different tree species, climate and N status. Forest Ecol. Manag. 260, $511,2010$.

31. MOLLON L.C., NORTON G.J., TRAKAL L., MORENOJIMENEZ E., ELOUALI F.Z., HOUGH R.L., BEESLEY L. Mobility and toxicity of heavy metal(loid)s arising from contaminated wood ash application to a pasture grassland soil. Environ. Pollut. 218, 419, 2016.

32. JONES D.L., QUILLIAM R.S. Metal contaminated biochar and wood ash negatively affect plant growth and soil quality after land application. J. Hazard. Mater. 276, 362, 2014. 
33. MORAGUES-SAITUA L., ARIAS-GONZÁLEZ A., GARTZIA-BENGOETXEA N. Effects of biochar and wood ash on soil hydraulic properties: A field experiment involving contrasting temperate soils. Geoderma 305, 144, 2017.

34. REED E.Y., CHADWICK D.R., HILL P.W., JONES D.L. Critical comparison of the impact of biochar and wood ash on soil organic matter cycling and grassland productivity. Soil Biol. Biochem. 110, 134, 2017.

35. TESSIER A., CAMPBELL P.G.C., BISSON M. Sequential extraction procedure for the speciation of particulate trace metals. Anal. Chem. 51, 884, 1979.

36. RAURET G., LOPEZ-SANCHEZ J.F., SAHUQUILLO A., RUBIO R., DAVIDSON C., URE A. Improvement of the $\mathrm{BCR}$ three step sequential extraction procedure prior to the certification of new sediment and soil reference materials. J. Environ. Monit. Assess 1, 57, 1999.

37. PRUDENT P., DOMEIZEL M., MASSINI C. Chemical sequential extraction as decision-making tool: application to municipal solid waste and its individual constituents. Sci. Tot. Environ. 178, 55, 1996.

38. JUKIĆ M., ĆURKOVIĆ L., ŠABARIĆ J., KEROLLIMUSTAFA M. Fractionation of heavy metals in fly ash from wood biomass using the BCR sequential extraction procedure. Bull. Environ. Contam. Toxicol. 99, 524, 2017.

39. Using bio-ash as fertilizer [in] Materials of project "The heat from indigenous biomass" co-financed from European Regional Development Fund under the CrossBorder Cooperation Programme Poland (Lubuskie Province) - Brandenburgia 2007-2013 [In Polish and German]. Available online: http://www.projekt-biomasse. $\mathrm{de} /$ pl/wyniki-projektu/wyniki-projektu.html (accessed on 03.10.2017).

40. FUKASAWA T., HORIGOME A., TSU T., KARISMA A.D., MAEDA N., HUANG A-N., FUKUI K. Utilization of incineration fly ash from biomass power plants for zeolite synthesis from coal fly ash by hydrothermal treatment. Fuel Process. Technol. 167, 92, 2017.

41. ZHUANG X.Y., CHEN L., KOMARNENI S., ZHOU C.H., TONG D.S., YANG H.M., YU W.H., WANG H. Fly ash-based geopolymer: clean production, properties and applications. J. Clean Prod. 125, 253, 2016.

42. KALEMBKIEWICZ J., CHMIELARZ U. Functional speciation and leachability of titanium group from industrial fly ash. Fuel 123, 73, 2014.

43. SOČO E., KALEMBKIEWICZ J. Removal of copper(II) and zinc(II) ions from aqueous solution by chemical treatment of coal fly ash, Croat. Chem. Acta 88, 267, 2015.

44. FAPOHUNDA C., AKINBILE B., SHITTU A. Structure and properties of mortar and concrete with rice husk ash as partial replacement of ordinary Portland cement - A review. Int. J. Sust. Built Environ. In press, 2017.

45. GRAU F., CHOO H., HU J.W., JUNG J. Engineering behavior and characteristics of wood ash and sugarcane bagasse ash. Materials 8, 6962, 2015.

46. SIDDIQUE R. Waste materials and by-products in concrete, 1st ed.; Springer-Verlag: Berlin Heidelberg (Germany), 307, 2008.

47. KIKAMÄGI K., OTS K., KUZNETSOVA T. Effect of wood ash on the biomass production and nutrient status of young silver birch (Betula pendula Roth) trees on cutaway peatlands in Estonia. Ecol. Eng. 58, 17, 2013.
48. FERNÁNDEZ-DELGADO JUAREZ M., GÓMEZBRANDÓN M., INSAM H. Merging two waste streams, wood ash and biowaste, results in improved composting process and end products. Sci. Total Environ. 511, 91, 2015.

49. PANDEY V.C., SINGH N. Impact of fly ash incorporation in soil systems. Agr. Ecosys. Environ. 136, 16, 2010.

50. MOZGAWA W., KRÓL M., DYCZEK J., DEJA J. Investigation of the coal fly ashes using IR spectroscopy. Spectrochim. Acta A Mol. Biomol. Spectrosc. 132, 889, 2014.

51. SHI R., LI J., JIANG J., MEHMOOD K., LIU J., XU R., QIAN W. Characteristics of biomass ashes from different materials and their ameliorative effects on acid soils. J. Environ. Sci. (China) 55, 294, 2017.

52. KOK M. V., ÖZGÜR E. Thermal analysis and kinetics of biomass samples. Fuel Process. Technol. 106, 739, 2013.

53. WANG W., LIU X., ZHENG Y. Quantitative chemical composition determination and thermal analysis for typical biomass ashes in China. Asia. Pac. J. Chem. Eng. 9, 751, 2014.

54. FEBRERO L., GRANADA E., PÉREZ C., PATIŇO D., ARCE E. Characterisation and comparison of biomass ashes with different thermal histories using TG-DSC. J. Therm. Anal. Calorim. 118, 669, 2014.

55. HUANG S., WU S., WU Y., GAO J. The physicochemical properties and catalytic characteristics of different biomass ashes. Energ. Source Part A 36, 402, 2014.

56. NIU Y., TAN H., HUI S. Ash-related issues during biomass combustion: Alkali-induced slagging, silicate melt-induced slagging (ash fusion), agglomeration, corrosion, ash utilization, and related countermeasures. Prog. Energy Combust. Sci. 52, 1, 2016.

57. KASTNER J.R., MILLER J., KOLAR P., DAS K.C. Catalytic ozonation of ammonia using biomass char and wood fly ash. Chemosphere 75, 739, 2009.

58. KUTCHKO B.G., KIM A.G. Fly ash characterization by SEM/EDS. Fuel 85, 2537, 2006.

59. FLANIGEN E.M. Molecular sieve zeolite technology - the first twenty-five years. Pure Appl. Chem. 52, 2191, 1980.

60. OGUNDIRAN M.B., OSIBANJO O. Mobility and speciation of heavy metals in soils impacted by hazardous waste. Chem. Spec. Bioavailab. 21, 59, 2009.

61. FIOL N., VILLAESCUSA I. Determination of sorbent point charge: usefulness in sorption studies. Environ. Chem. Lett. 7, 79, 2009.

62. MURAYAMA N., TANABE M., YAMAMOTO H., SHIBATA J. Reaction, Mechanism and application of various zeolite syntheses from coal fly ash. Mater. Trans. 44, 2475, 2003.

63. PATHAN S.M., AYLMORE L.A.G., COLMER T.D. Properties of several fly ash materials in relation to use as soil amendments. J. Environ. Qual. 32, 687, 2003.

64. DAVIDOVITS J. Geopolymer Chemistry and Applications $4^{\text {th }}$ edition. Institut Géopolymère: Saint-Quentin (France), 3, 2015.

65. VAN DEVENTER J.S.J., PROVIS J.L., DUXSON P. Technical and commercial progress in the adoption of geopolymer cement. Miner. Eng. 29, 89, 2012. 
